\title{
HIRUDOTHERAPY IN TREATMENT OF CHRONIC GENERALISED PERIODONTITIS
}

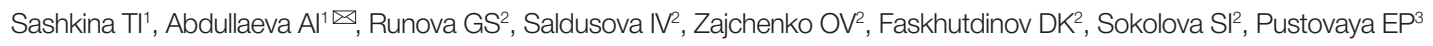

${ }^{1}$ Pirogov Russian National Research Medical University, Moscow, Russia

${ }^{2}$ Al Yevdokimov Moscow State University of Medicine and Dentistry, Moscow, Russia

${ }^{3}$ Peoples Friendship University of Russia, Moscow, Russia

\begin{abstract}
Chronic generalized periodontitis (CGP) is a disease associated with low susceptibility to the therapeutic protocols applied; practitioners tend to characterize it as a disease presenting certain difficulties. Therefore, the search for drugs and methods capable of increasing the efficacy of CGP therapy is an ongoing process. Additional problems, which have to do with either with antibiotic resistance or increased sensitivity to drugs, also occur quite often. This study aimed to assess the possibility of applying hirudotherapy in the context of conservative treatment of CGP. 50 patients with CGP without somatic pathology were examined and treated. The participants were divided into two groups $(n=25)$, all group members of about the same age. At the first stage, the treatment followed the accepted standard: professional oral hygiene procedures, antimicrobial and anti-inflammatory drugs, demonstration of proper personal oral hygiene routines. Then, first group went through a monthlong hirudotherapy course that consisted of 6 to 8 individual procedures. Second group was observed throughout this period with the aim to control the level of their compliance with the oral hygiene routines they were trained. Having analyzed the results, we found that hirudotherapy was more effective than what was prescribed to the second (control) group. The papillary marginal alveolar index (PMA), which reflects the severity of inflammation and gum bleeding, decreased significantly in the first group, where medicinal leeches were used: in the patients with severe CGP it went down by $6 \%$, in those with moderately severe CGP the index decreased by $24 \%$ and the participants whose CGP was only light had the PMA go down by $2 \%$. Thus, we have demonstrated the efficacy of hirudotherapy in the context of conservative CGP treatment, which allows recommending this method for inclusion into clinical practice.
\end{abstract}

Keywords: chronic generalized periodontitis, hirudotherapy, periodontal indices

Author contribution: Sashkina TI, Abdullaeva Al — research planning, data processing, manuscript editing; Zaychenko OV and Pustovaya EP — data processing, statistical data processing, manuscript editing; Sokolova SI, Saldusova IV — data processing, manuscript editing; Faskhutdinov DK, Runova GS — data collection, manuscript drafting.

Compliance with ethical standards: the study was approved by the Ethics Committee of Pirogov Russian National Research Medical University (protocol № 981 of June 24, 2019).

$\triangle$ Correspondence should be addressed: Aytan I. Abdullaeva

Ostrovityanova 1, Moscow, 117997; aitanka@list.ru

Received: 25.06.2019 Accepted: 25.07.2019 Published online: 18.08.2019

DOI: $10.24075 /$ brsmu.2019.052

\section{ГИРУДОТЕРАПИЯ В ЛЕЧЕНИИ ХРОНИЧЕСКОГО ГЕНЕРАЛИЗОВАННОГО ПАРОДОНТИТА}

Т. И. Сашкина'

${ }^{1}$ Российский национальный исследовательский медицинский университет имени Н. И. Пирогова, Москва, Россия

${ }^{2}$ Московский государственный медико-стоматологический университет имени А. И. Евдокимова, Москва, Россия

${ }^{3}$ Российский университет дружбы народов, Москва, Россия

\begin{abstract}
Хронический генерализованный пародонтит (ХГП) - заболевание, которое представляет определенные трудности для специалистов, поскольку характеризуется устойчивостью к применяемой терапии. Поэтому постоянно идет поиск препаратов и методов, позволяющих повысить эффективность лечения ХГП. Нередко возникают дополнительные проблемы, которые связаны либо с антибиотикорезистентностью, либо с повышенной чувствительностью к препаратам. Целью исследования было определить возможность использования гирудотерапии при консервативном лечении пациентов с ХГП. Было обследовано и пролечено 50 пациентов с ХГП, не имеющих соматической патологии. Они были разделены на две группы по 25 человек, примерно одного возраста. В каждой из групп сначала проводили лечение в соответствии с принятым стандартом: назначали профессиональные гигиенические процедуры, антимикробные и противовоспалительные препараты, обучали индивидуальной гигиене. Затем пациентам первой группы проводили курс гирудотерапии, состоящий из 6-8 процедур в течение месяца. При этом пациенты второй группы находились на диспансерном учете с целью контроля гигиены полости рта. Анализ полученных результатов показал более высокую эффективность гирудотерапии по отношению к группе сравнения. В группе, в которой использовали медицинские пиявки, происходило достоверное снижение папиллярно-маргинально-альвеолярного индекса (РМА), характеризующего интенсивность воспалительного процесса и кровоточивость тканей десны: на $32 \%$ при легкой степени тяжести, на 24\% при средней степени тяжести, на 6\% при тяжелой степени тяжести ХГП. Таким образом, показана эсфективность гирудотерапии в консервативном лечении пациентов с ХГП, что позволяет рекомендовать этот метод в клиническую практику.
\end{abstract}

Ключевые слова: хронический генерализованный пародонтит, гирудотерапия, пародонтальные индексы

Информация о вкладе авторов: Т. И. Сашкина, А. И. Абдуллаева - планирование исследования, обработка полученных данных, редактирование рукописи; О. В. Зайченко и Е. П. Пустовая - обработка полученных данных, статистическая обработка данных, редактирование рукописи; С. И. Соколова, И. В. Салдусова - обработка полученных данных, редактирование рукописи; Д. К. Фасхутдинов, Г. С. Рунова - сбор данных, написание черновика рукописи.

Соблюдение этических стандартов: исследование было одобрено этическим комитетом РНИМУ имени Н. И. Пирогова (протокол № 981 от 24 июня 2019 г.).

$\bigotimes$ Для корреспонденции: Айтан Измировна Абдуллаева ул. Островитянова, д. 1, г. Москва, 117997; aitanka@list.ru

Статья получена: 25.06.2019 Статья принята к печати: 25.07.2019 Опубликована онлайн: 18.08.2019

DOI: $10.24075 /$ vrgmu.2019.052 
According to the $\mathrm{WHO}$, over $90 \%$ of the world's population suffer from chronic inflammatory periodontal diseases that run for a long period of time and resist treatment, leading to tooth loss, development of chronic diseases of the gastrointestinal tract, cardiovascular and other systems, which negatively affect health and quality of life of such people [1, 2]. Therefore, periodontitis is more than a medical problem, it is also a social one since it affects the lives of people. Successful periodontitis therapies are standing problem for dental professionals. There are various approaches to the treatment of periodontitis. Surgical, physiotherapeutic and alternative treatment methods, like naturopathy, often complete the courses of mandatory antimicrobial therapy and professional oral hygiene procedures. According to the published literature, hirudotherapy is one of the methods applied to counter various inflammatory diseases. Leech saliva is a bacteriostatic agent, which means it reduces the bacterial load on periodontal tissues and normalizes hemostasis [3-6]. This fact encouraged us to study hirudotherapy as a treatment modality that can be a part of the conservative CGP therapy $[4,5]$.

The goal of this research effort was to learn the efficacy of hirudotherapy in the complex conservative treatment of CGP patients.

\section{METHODS}

The study involved 50 patients, 21 male and 29 female, aged 32 to 52 years, suffering from light, moderately severe and severe CGP. Inclusion criteria: signed informed consent; the presence of CGP absence of concomitant somatic pathology at the age of 32 to 52 years; taken training in wound care; preliminary therapy in accordance with the standard approved by the Ministry of Health of the Russian Federation; Exclusion criteria: the presence of concomitant somatic pathology; age younger than 32 and older than 52 years; non-compliance with the medical requirements and non-compliance with oral hygiene; lack of prior therapy in accordance with the standard approved by the Minister of Health of the Russian Federation. They were divided into two groups so as to have the clinical and functional characteristics. 25 patients formed the treatment group: 9 (36\%) had light CGP, 9 (36\%) other - moderately severe CGP and in 7 (28\%) patients the disease developed into the severe stage. The distribution of CGP stages in the control stages was the same (Fig. 1). No participant had a somatic pathology aggravating the disease in question. We used the

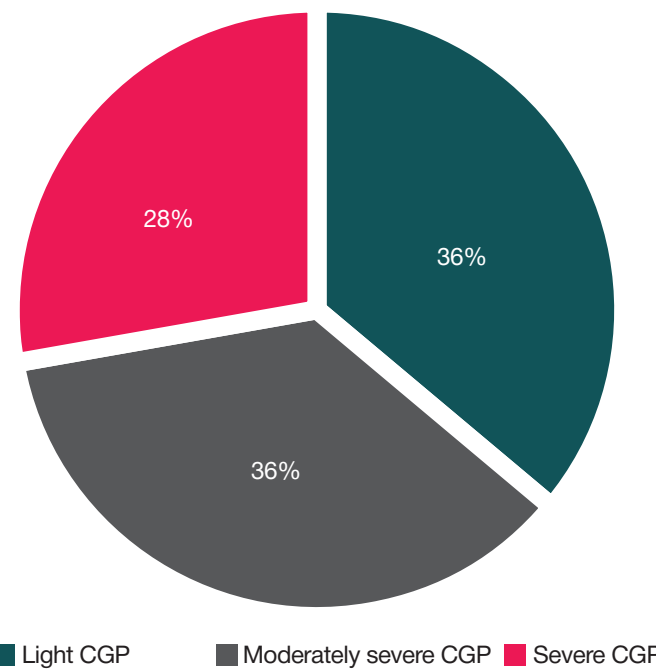

Fig. 1. Distribution of CGP patients in groups depending on the severity of the disease $(n=25)$ objective indices to assess the efficacy of treatment: PMA and the Green-Vermillion index, which allow monitoring the degree of inflammation.

For the treatment group patients, a week's course included the standard antimicrobial, anti-inflammatory therapy, professional oral hygiene procedures, which were followed by hirudotherapy, i. e. attaching leeches to the inflamed periodontal tissues (Fig. 2). We used the standard size $(0.6-1 \mathrm{~g})$ medicinal leeches. The course, which ran for a month, consisted of 6-8 procedures conducted twice a week. The leeches were attached 2 hours after eating; the patients were warned that their oral cavities should be free from specific odors, such as those of onion, garlic, mouth rinse, coffee, cardamom. Also, the patients were forbidden to smoke and to use perfumes 5-6 hours before their visits to the dentist.

The patients in the control group received standard treatment. Instead of hirudotherapy, they were observed with the aim to control how they follow the prescribed personal oral hygiene routines.

We applied the Student's test in statistical processing of the obtained results; the confidence level was set at 95\% $(p<0.05)$. STATISTICA 10 software (Round Rock; USA) was used to perform the processing.

\section{RESULTS}

Having analyzed the data collected, we learned that medicinal leeches augmented the effect of standard therapy in the treatment group, and the indices describing state of periodontal tissue showed a continuing downward trend. After treatment, the PMA index was at the lowest point in light CGP cases: from $21.89 \pm 2.03$ to $14.89 \pm 2.14(p<0.05)$. In patients with moderately severe CGP the PMA decrease was less obvious: from $33.74 \pm 3.57$ to $25.74 \pm 3.21$. In the cases where the disease has progressed to severe stage, PMA went down slightly, but the decrease could not be called significant: from $67.85 \pm 1.28$ to $64.24 \pm 1.26(p \geq 0.05)$ (Fig. 3). Compared to the treatment group, the results registered in the control group were less pronounced. The PMA index decreased from $24.91 \pm 2.73$ to $19.91 \pm 2.08$ $(p<0.05)$ in light CGP cases, which is significant but not as great as what was seen in the treatment group. In patients with moderately severe CGP the index changed from $33.61 \pm 3.14$ to $28.36 \pm 3.44$, and in severe CGP cases - from $67.15 \pm 1.28$ to $66.85 \pm 1.18$ (Fig. 4), both the former and the latter change being non-significant $(p \geq 0.05)$. Comparing the

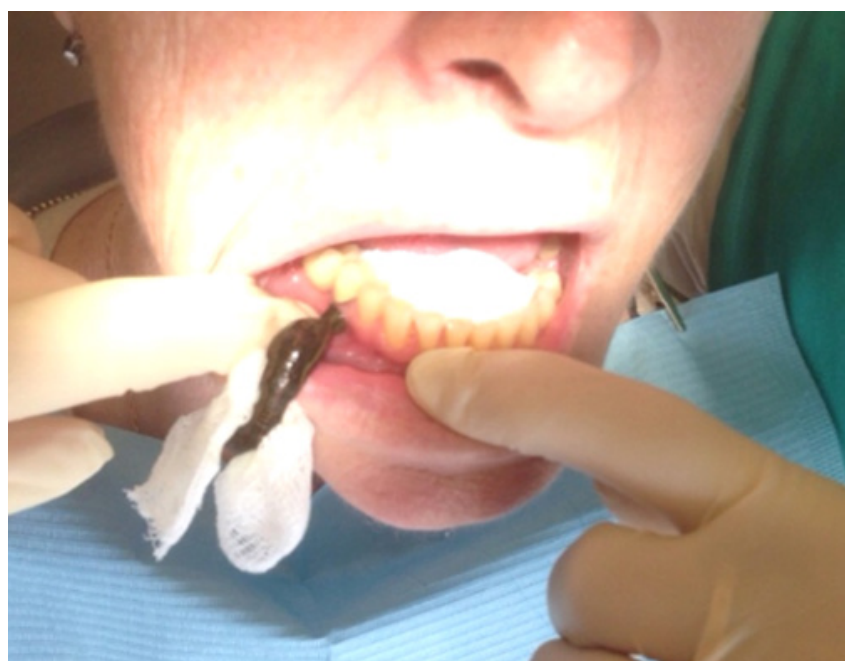

Fig. 2. Applying medicinal leeches to a CGP patient. A standard-sized medicinal leech is attached to the inflamed periodontal tissues 


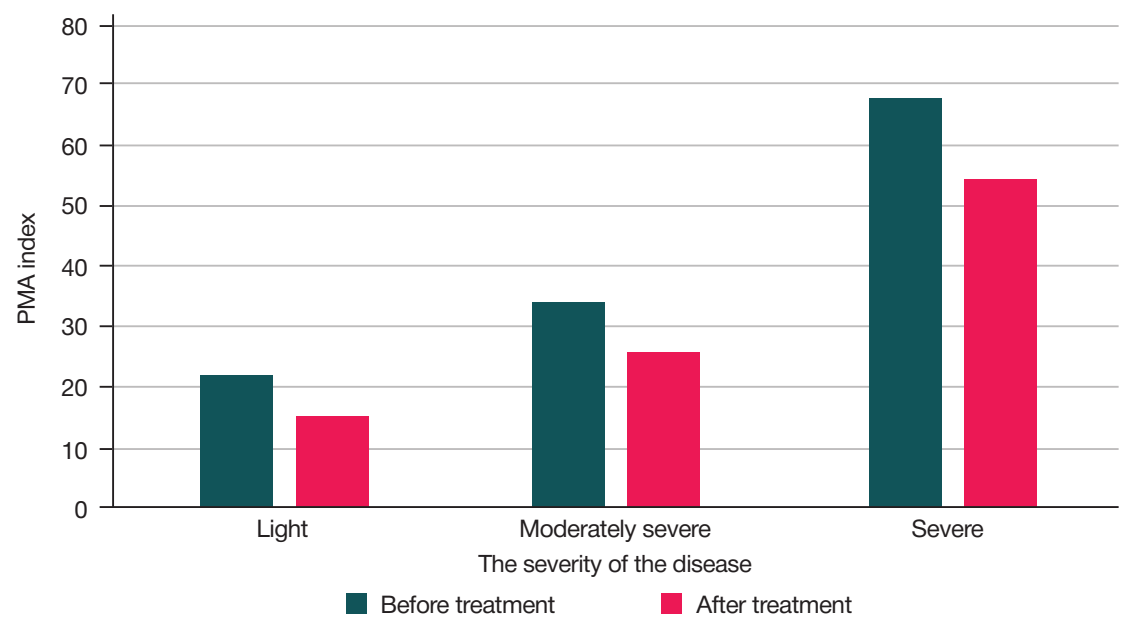

Fig. 3. PMA index dynamics, treatment group $(n=25)$

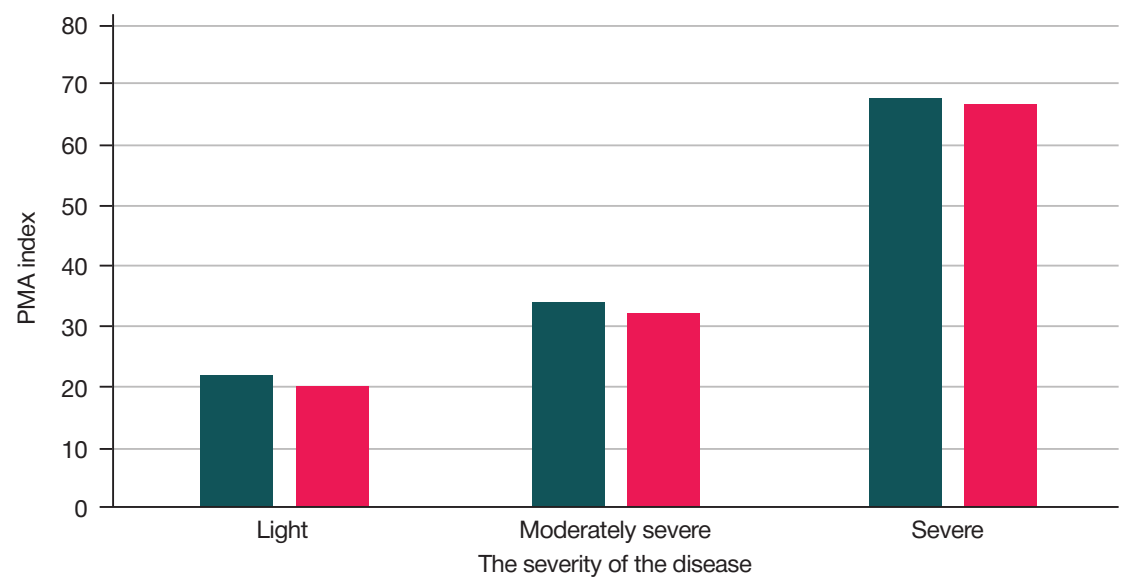

Before treatment

After treatment

Fig. 4. PMA index dynamics, control group $(n=25)$

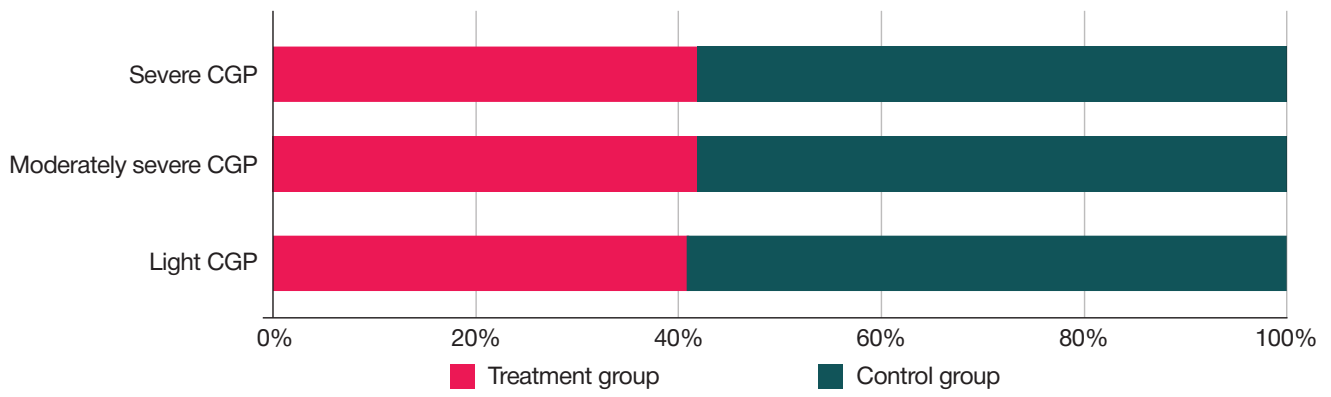

Fig. 5. PMA index comparison after treatment, control and treatment groups

data collected in both groups, we discovered that the protocol applied in the treatment group delivered a stronger clinical effect in light and moderately severe CGP cases (Fig. 5).

\section{DISCUSSION}

To a certain extent, the findings of our study are consistent with those of a paper published in 2014 that described introduction of hirudotherapy and Lipin (liposomal drug) to the periodontitis treatment protocol. The authors of that paper wrote about the suggested complex approach being more effective than the standard one, but did not measure the contribution of each component to the final result of the treatment [6]. We showed that medicinal leeches, applied separately, help arrest inflammation in CGP patients, reduce edema, arterial hyperemia and gum bleeding. Application of medicinal leeches made the effect from standard treatment more pronounced and lasting (compared to the control group), which increased duration of the remission. The dynamics of change of the indices monitored was positive; the change to the better was registered after 2-4 hirudotherapy procedures. The effect was stronger in light and moderately severe CGP cases.

\section{CONCLUSIONS}

The study demonstrated a positive effect hirudotherapy offers as part of the CGP treatment protocol. This treatment tactic significantly increases the efficacy of standard therapeutic measures and significantly reduces the inflammatory potential of periodontal tissues: pain, itching, bleeding gums. Given the growing antibiotic resistance and high sensitivity of population to antibacterial drugs in particular, hirudotherapy may be the method of choice, and sometimes one of the few treatment modalities applicable to certain groups of population. 


\section{References}

1. Sashkina TI, Poryadin GV, Runova GS, Dubrovin DS, Faskhutdinov DK, Markina ML, et al. The application of an immunomodulator for the correction of the inflammatory process in periodontal tissues of the patients presenting with chronic generalized periodontitis. Rossiiskaya stomatologia. 2016; 9 (3): 38-41. In Russian.

2. Grudyanov Al, Tkacheva ON, Avraamova TV, Khvatova NT. The relationship between inflammatory periodontal diseases and cardiovascular diseases. Rossiiskaya stomatologia. 2015; 94 (3): 50-5. In Russian.

3. Danilevskij NF. Zabolevaniya slizistoj obolochki polosti rta. M.: GEOTAR-Media, 2001. In Russian.

\section{Литература}

1. Сашкина Т. И., Порядин Г. В., Рунова Г. С., Дубровин Д. С., Фасхутдинов Д. К., Маркина М. Л., и др. Применение иммуномодулятора для коррекции воспалительного процесса в тканях пародонта у больных с хроническим генерализованным пародонтитом. Российская стоматология. 2016; 9 (3): 38-41.

2. Грудянов А. И., Ткачева О. Н., Авраамова Т. В., Хватова Н. Т. Вопросы взаимосвязи воспалительных заболеваний пародонта и сердечно-сосудистой патологии. Стоматология. 2015; 94 (3): 50-5.

3. Данилевский Н. Ф. Заболевания слизистой оболочки полости рта. М.: ГЭОТАР-Медиа, 2001
4. Tsepov LM, Tsepova EL, Tsepov AL. Marginal periodontitis: local focus of serious problems. Parodontologia. 2014; 3 (72): 3-10.

5. Trevilatto PC, de Brito RBJr, Scarel-Caminaga RM, de Souza AP, Sallum AW, Line SRP. Polymorphism in the tumor necrosis factoralpha gene (TNFA-308 G/A) is not associated with susceptibility to chronic periodontitis in a Brazilian population. Dentistry 3000. 2015; (3): 1

6. Abduvaliev AA, Daurekhanov AM, Hirudotherapy as a complex treatment of patients with reactive arthritis. Bulletin of KazNMU. 2017; (1): 249-52.

4. Ц Цепов Л. М., Цепова Е. Л., Цепов А. Л. Пародонтит: локальный очаг серьезных проблем. Пародонтология. 2014; 3 (72): 3-10.

5. Trevilatto PC, de Brito RBJr, Scarel-Caminaga RM, de Souza AP, Sallum AW, Line SRP. Polymorphism in the tumor necrosis factoralpha gene (TNFA-308 G/A) is not associated with susceptibility to chronic periodontitis in a Brazilian population. Dentistry 3000. 2015; (3): 1.

6. Абдувалиев А. А., Дауреханов А. М. Гирудотерапия в комплексном лечении больных реактивным артритом. Вестник КазНМУ. 2017; (1): 249-52. 